\title{
Adiponectin Receptor Protein 2
}

National Cancer Institute

\section{Source}

National Cancer Institute. Adiponectin Receptor Protein 2. NCI Thesaurus. Code C103978.

Adiponectin receptor protein 2 (386 aa, $\sim 44 \mathrm{kDa}$ ) is encoded by the human ADIPOR2 gene. This protein plays a role in adiponectin-mediated signal transduction. 